\title{
A DISTANT ECHO OF ECO-EPIDEMIOLOGY: A REVIEW
}

\section{Fernando Dias de Avila-Pires ${ }^{1}$}

\begin{abstract}
Epidemiology is here defined as "the study of distribution, frequency and causes of human diseases, and also the study of threats to health and the practices of public health for the prevention of specific diseases and all risks to health". Formerly directed to phenomena affecting populations, results of epidemiological investigations have been applied to individuals, especially in what concerns risk, what became known as "the great fallacy". Another distortion became known as "black-box epidemiology", the adoption of sanitary and public health measures without a sound knowledge of underlying biological factors in favor of the investigation of the correlates of risk. This led to the theory that diseases could be prevented by altering the environment, without the need for detailed knowledge of pathogenic mechanisms. Finally, Susser and Susser advocated a paradigm for an emergent era of eco-epidemiology, called the "Chinese boxes", in an allusion to the sets of boxes where each fits inside a larger box. This paper discusses in greater detail the disputes around such concepts and the pitfalls for the application of epidemiological theories to public health.
\end{abstract}

KEY WORDS: Eco-epidemiology; epidemiology; black-box; public health; risk.

\section{RESUMO}

Ecos distantes da eco-epidemiologia: revisão de conceitos

Epidemiologia é definida aqui como o estudo da distribuição, frequência e causas das doenças humanas e com o estudo dos riscos para a saúde e práticas de saúde pública para a prevenção de todos os riscos para a saúde. Dirigida inicialmente aos fenômenos que afetam populações, os resultados de investigações epidemiológicas têm sido aplicadas a indivíduos, em especial no que concerne a riscos, o que ficou sendo conhecido como a grande falácia. Uma outra distorção ficou

1 Departamento de Medicina Tropical, Instituto Oswaldo Cruz, FIOCRUZ, Rio de Janeiro, Brasil (retired). E-mail: favila@matrix.com.br.

Endereço para correspondência: E-mail: favila@matrix.com.br

Presented at the Round Table Eco-epidemiology, XVIII International Congress for TropicalMedicine and Malaria and XLVIII Congress of the Brazilian Society of Tropical Medicine. Rio de Janeiro, 2012.

Received for publication in: 2/10/2012. Accepted in: 6/3/2013. 
conhecida como epidemiologia de caixa-preta, ou seja, a adoção de ações sanitárias e de saúde pública sem conhecimento dos fatores biológicos subjacentes, em favor da investigação dos fatores de risco. Isso levou à teoria de que doenças poderiam ser prevenidas pela alteração do ambiente, independente do conhecimento detalhado dos mecanismos patogênicos. Finalmente, Susser e Susser defenderam um paradigma para uma era emergente da eco-epidemiologia, denominado caixas chinesas, uma alusão aos conjuntos de caixas que se encaixam umas nas outras. Este trabalho discute em maior detalhe as discussões sobre esses conceitos e as armadilhas que cercam a aplicação das teorias epidemiológicas para a saúde pública.

DESCRITORES: Eco-epidemiologia; epidemiologia; caixa-preta; saúde pública; risco.

\section{INTRODUCTION}

In 1954, Darrell Huff published a book, How to lie with statistics, that shows how to present data in an unconventional way, in order to prove your point or to mislead your opponents, through the manipulation of statistical charts and data.

Statistics have much to do with epidemiology, but statistics are a double-edged weapon: and as such, we must use them with great care. Whatever resources, formulae, and calculations we perform, the results will be no better than the original hard data, and the correlations derived from our analyses must be valid from biological and ecological points of view.

I am fond of the Editor's quotation against the misuse of statistical correlations in a 1961 issue of the New England Journal of Medicine. Referring to the great debate concerning the relationship between cigarette smoking and lung cancer. he poses the question "Why does getting cancer make one smoke so much?", as a small boy might ask his mother, after passing several crippled peddlers in the street: "Why does selling pencils cut off both your legs?".

Epidemiology is the search for causes of diseases and health hazards, and the establishment of correlations. Its original meaning was recently discussed by Pino and Hernández (2008).

Coura (2004) defined epidemiology as

the study of distribution, frequency and causes of human diseases, and also the study of threats to health and the practices of public health for the prevention of specific diseases and to all risks to health.

This is the definition I will adopt in the following text.

I agree with Stallones' (1980) contention that only one epidemiology exists, though I cannot agree that "the same tool can be employed in different ways". I have proposed elsewhere that to deal with multidisciplinary problems, we must be equipped with a manifold tool, like a Swiss army knife. We must have a fair understanding and ability to use the particular tools and research methods of the distinct areas of knowledge involved, from those of the social sciences to those of the natural sciences and mathematics. 
It is important to bear in mind that empirical public health practices have lead to an improvement in living conditions through the centuries, especially the practices concerned with public hygiene and sanitation, irrespective of the theories involved: miasmatic, contagious, or the microbial infections of Pasteur. The first example that comes to mind is the control of malaria in ancient Rome through the digging of canals and the drainage of marshes. The miasmatic theory persisted until the times of Pasteur - and a form of it lingers to this day, under the guise of pollution. The historical changes in the theories of disease - from miasmatic to microbial infection - did not alter epidemiological correlations based upon population/ environment studies. This view would later be labeled "black box epidemiology", and stand at the center of a bitter debate.

In this review of the literature, I did not attempt to analyze the vast amount of publications on this complex subject, but to highlight the relevant issues discussed by epidemiologists concerning the health of populations and its impact upon the health of individuals.

Recent reviews of the historical development of epidemiology are those of Pearce (1996), Coura (2004), Rothman (2007), and Susser and Stein (2009). An earlier analysis of epidemic theory was published by Serfling (1952). As a comprehensive text of epidemiology and a discussion of its principles, methods, pitfalls, and achievements, I consider Peller's text (1967) so far to be unsurpassed.

\section{THE ORIGINS OF A FALLACY}

In the Nineteenth Century, the concept of society was established and Sociology was born. Herbert Spencer (Rumney, 1934), August Comte (1839), Karl Marx (Marx and Engels, 1984), Émile Durkheim (1894), and Max Weber (1991) laid the foundations of this new field.

When Durkheim proposed his rules for the study of sociology, he described the emergence of new properties, arising from the combination of elements present in a lower hierarchical level of complexity. This means, in short, that the whole is larger than the sum of its parts. In order to explain this concept, Durkheim mentioned the nature of cells: formed by mineral particles, their living properties are not found in the atoms of hydrogen, oxygen, or carbon. Life emerges from the integration of the elements of a cell, but it is not present in each of its particles. In the same manner, the properties of a society as a whole are not found in each individual that make up a particular social group. As Durkheim pointed out, Notre règle n'implique donc aucune conception métaphysique, aucune spéculation sur le fond des êtres. Similar remarks were made by Bertalanffy (1950) and more recently by Bergandi (1995). See also, Robinson, (1950), Selvin (1958), Schwartz (1994) and Morgenstern (1982), on the subject of levels of complexity and ecological correlations.

Ludwig von Bertalanffy, originally an embryologist, discussed the concept of levels of complexity during the 1920s, published an abstract on his theories in 
1950, and a book in 1968 - whereupon he became famous - although controversial. He stressed the importance of avoiding "reductionism" and the extension of ideas across the barrier of hierarchic levels. According to this logical principle, correlations must be made at a single level of complexity. The phenomenon of herd immunity is a good example: it operates at the level of populations but evidently, not at the individual level.

It is the raison-d'être of the actuarial/insurance business, which is said to succeed in turning the incertitude of life-and-death into the certitude of profit.

In the field of medicine, an example is the case when the use of data derived from studies of populations or groups is applied to individuals, at the clinic. Stallones $(1980)$ and Rose $(1985,2001)$ called attention to this fact. The dubious results of such practice (e.g. Poole, 1994), make matters worse through the disregard of the distinction made by Canguilhem $(1943,1996)$ between the two separate meanings of what we regard as "normal": what is usual in a population or group, and what conforms to an established empirical fixed normal value.

In epidemiological literature, reductionism - the application of results valid in population studies to individuals - became known as "the great fallacy", starting a flood of bitter arguments (e.g. Selvin, 1958, Robinson 1950, Morris 1957, Morgenstern 1982, Schwartz 1994, Diaz-Roux 1998, March and Susser 2006, Portnov et al. 2007). A good example is Marcel Goldberg's paper on Cet obscur objet de l'épidémiologie.

It is amazing to see how long those ideas took to be understood and accepted - if at all - by epidemiologists (Rose, 2001; Schwartz and Diez-Roux, 2001), and especially by those who became epidemiologists from a clinical background, as pointed out by Rose (2001). Many authors could not understand how diseases reside in an individual, but the causes of disease in a population would be distinct. (Schwartz and Dietz-Roux, 2001).

In his seminal paper, Rose $(1985,2001)$ stated that "to find the determinants of prevalence and incidence rates, we need to study characteristics of populations, not characteristics of individuals". He made a distinction between the determinants of individual cases, and the determinants of the rate of incidence in populations:

It has proved easy to show strong associations between population mean values for saturated fat intake versus serum cholesterol level and coronary heart disease incidence, sodium intake versus blood pressure, or energy intake versus overweight.

And he admonished that:

Within populations it has proved almost impossible to demonstrate any relation between an individual's diet and his serum cholesterol level; and the same applies to the relation of individual diet to blood pressure 
and to overweight. But at the level of populations it is a different story. The determinants of incidence are not necessarily the same as the causes of cases.

Schwartz (1994) deemed these attempts "a logical fallacy inherent in making causal inferences from group data to individual behaviors, and was followed by a host of critics". One of the critics was Pearce (1996).

Schwartz and Diez-Roux, commenting on Rose's paper, were the only authors to refer to Durkheim's theory of social facts as being at the root of the explanation of the epidemiological fallacy.

One might argue with the principle of precaution, and prevention of risk as applied to individual patients, but results are debatable, and certainly it is not applicable to mental diseases, where a diagnosis carries serious legal consequences.

As for the questions raised by the multicausality of diseases, Krieger discussed the problems in relation to the theory of the "web of causation" (Krieger, 1994). In her paper, Krieger lists the textbooks published in the United States since 1970, dealing with epidemiological theory, history and the "web of causation". The idea of the web of causation as opposed to single-cause correlations was first proposed by Brian MacMahon et al. in 1960.

Another common source of error when establishing a correlation is the disregard for the search for a biological basis that may justify an association, a fact that has been pointed out by several authors such as Peller (1967), Susser (1973), and Chia (2000). This is well illustrated in McCormick's (2001) paper, commenting on Rose's (2001) critical argument, and stating that dietary manipulations have very limited effects upon cholesterol levels, just as the reduction of salt intake has little result in lowering blood pressure.

This confusion is compounded by a poor understanding of the concept of disease, and the lack of distinction between what is real, objective - and directly observable, and what is constructed (Avila-Pires, 2008). Pathological lesions are present in individuals. They may be analyzed at successive levels of organization: molecular, cellular, and histological, each one with its particular and limited characteristics. They leave imprints in fossils, and are thus found in the remains of animals that lived and died long before man appeared upon the Earth. The nature of lesions may be identified macroscopically, microscopically or through DNA analysis.

Diseases though, are abstract concepts. They are social constructs. They are collective and composite categories that result from the sum of combined observations of individual case histories, recorded in distinct places and at different times, by different observers. The full range of possible signals and symptoms are seldom, if at all, present in a single patient. A characteristic of the composite or collective quality of disease descriptions is the frequent use of qualifying expressions such as "in many cases", "frequently", "it may occur", "it was observed that". Also, text-book drawings usually represent a composite picture of a collective description. 


\section{ON THE NATURE OF EPIDEMIOLOGICAL RESEARCH}

Morgenstern (1982) defined ecological research as "empirical investigations involving the group as the unity of analysis". It is used - and useful - for generating or testing etiological hypotheses, explaining disease occurrence, and for evaluating the effectiveness of public-health-oriented, interventions (see also Robinson, 1950).

Susser and Susser (1996a) are credited with the proposal of a redirection of epidemiological research and training in epidemiology under the name Eco-Epidemiology (March and Susser, 2006). They claim that the epidemiological research of late has become focused primarily on the study of risk and upon individual risk behavior (Morabia, 1996; Susser, 1998; Susser, 2004).

Susser (1989) considered that epidemiological research directed at problem solving and at the prevention of disease in public health had declined towards 1950 and was passé by the 1970s. Furthermore, he criticized the transition from infectious to chronic diseases, which would be termed the "epidemiological transition" by Omran (1971).

According to Weed (1998), Peto (1984) named "black box epidemiology" the ignorance of biological factors in favor of the investigation of correlates of risk. At the same time, Loomis and Wing (1990) criticized those of his contemporaries who were "guided by the principle that the origins of disease are environmental in a very broad sense", what he deemed the "black box" view. This led to the theory that diseases could be prevented by altering the environment, "without the need for detailed knowledge of pathogenic mechanisms", while Savitz defended the tradition of "black box" epidemiology, arguing that it allows for disease prevention in the absence of a clear understanding of its mechanisms.

Later, Susser and Susser (1996a) declared that:

The present era of epidemiology is coming to a close. The focus on risk factors at the individual level - the hallmark of this era - will no longer serve. We need to be concerned equally with causal pathways at the societal level and with pathogenesis and causality at the molecular level.

This paper was followed by Part 2, dealing with the future of epidemiology (Susser and Susser, 1996b), as we will see below.

Susser and Susser (1996b) advocated a paradigm for an emergent era of eco-epidemiology, called "Chinese boxes", in an allusion to the sets of boxes where each fits inside a larger box. At the same time, they stressed that the adoption of the eco-epidemiology paradigm is not a call for more studies of an ecological nature, but a call to examine the behavior of disease at those levels of organization, beyond and within the individual. A brief résumé of the black box debate is found in Weed (1998). But, as late as 2004, authors supported the idea of an epidemiology directed 
towards public health and the analysis and prevention of risk (Koopman, 1996; Greenland and Robins, 1986; Greenland et al. 2004).

In 1999 Schwartz, E. Susser and M. Susser anticipated a future for epidemiology. Criticisms concerning premature and dubious association of risk factors and disease, the inadequacy of epidemiology to provide solutions to public health issues, and the neglect of the social environment where disease occur, among others, formed the basis of their arguments.

Another source of confusion is the use of false units, aggregates, or categories of analysis such as race. In a message for an online discussion group, Stephen Morse (1995) called attention to the fact that definitions of race, ethnicity, culture, and nationality are often used inaccurately in the epidemiological literature. Categories such as Hispanic, Caucasian; and African-American, have no meaning as applied to disease

As Rose (2001) stressed, confounding genetic or behavioral characteristics of individuals with the incidence of diseases in groups or populations is a regrettable error, and migrants, whatever the color of their skin, tend to acquire the disease rates of their country of adoption.

Attempts at eradicating such confounding variables from epidemiological analyses have, so far, been innocuous. See, for instance, Smaje (1996); Templeton (1999); Root (2003); Pena (2008), and Bradby (2012).

\section{ECO IN ECO-EPIDEMIOLOGY}

In 2004, Ezra Susser revived the debate over the importance of risk-factors, or black box epidemiology and the individualization of the idea of risk. While she accepted the arguments put forward by Greenland et al. (2004), and others showing the importance of the analysis of risk as a basis for the understanding of the causes and the improvement of public health, she deplores the limitation of epidemiology to what became known as black box research, and insisted on the need for consideration of multiple levels of causation. At the same time, she cautions against reductionism, and advocates the use of different approaches for the correct identification of the causal relationships at each level. She referred in passing to the relation of epidemiology to human ecology and to the use of different meanings of the term ecology by epidemiologists.

Human ecology is not restricted to health matters (Avila-Pires, 1999).

Ecological studies, in epidemiology, do not always imply the use of ecological (s.s.) theories and principles, which are based upon the concept of ecosystem, defined by Tansley (1935) as "an open system of circulation of nutrients and the transfer of energy through a hierarchical succession of trophic levels, from producers (green plants) to primary consumers, predators, parasites, and finally, decomposers". 
Some authors define ecological studies in epidemiology as those directed at population analyses (Robinson, 1950), while others include the environment, without a proper definition of what environment means (Diez-Roux, 1998). The misuse of ecological ideas and terms has been discussed in detail by Avila-Pires (1995).

References to the Hippocratic idea of a close relationship of diseases and the factors of a local physical environment (water, air, and places) as the beginnings of ecology are anachronistic. The same applies to Linnaeus' theories on the Economy of Nature, the existing equilibrium being attributed by him to the Creator's design. In 1859, Charles Darwin called attention to an observable fact he envisaged to be of fundamental relevance: "Let it be borne in mind how infinitely complex and close-fitting are the mutual relations of all organic beings to each other and to their physical conditions of life".

The twofold aspects of evolution by natural selection, as envisaged by Darwin turned out to be the two main trends of ecological relationships, defined by Ernst Haeckel (1866) as "the study of the relationships of organisms with one another, and with the non-biotic factors of the environment".

The modern concept of the ecosystem was only achieved after the demonstration by Pasteur (1858) of the biological nature of the putrefaction and decomposition of organic matter by microorganisms, and the non existence of biogenesis, or spontaneous generation. Claude Bernard (1878-1879) and Tyndall (1881) described clearly the recycling of nutrients in nature.

In 1913, Shelford considered ecology as part of general physiology, which treats the organism in its totality, in relation with its environment. This became known as auto ecology, in opposition to synecology, or the ecological study of communities. In 1939, Clements and Shelford remarked that:

The very essence of ecology is the synthesis derived from the exhaustive analysis of the community and its habitat ...the fragmentation of animal communities on the basis of taxonomic groups is greatly to be deplored, since it destroys the last semblance of unity.

Likewise, the epidemiological analyses and models that restrict the components of a cycle of disease transmission to one, or at best, a few selected reservoirs, vectors and man, are likely to leave out most of its real nature and the significance of those cycles.

Medical ecology is centered on the relationships between different elements that lead to disease in a biological community. Man is one of those elements. In epidemiology, the emphasis is upon a human population harboring a disease or condition which affects its health as measured by rates of prevalence and/ or incidence (Avila-Pires, 2000). 


\section{ECHOES OF A DEBATE}

Little agreement arose from those long and sometimes acrimonious debates. Being so, the following issues remain open to discussion and dispute:

1. The fallacy debate involving the theory of levels of complexity, and the use of data valid for populations, in the clinic. According to Rose, there is a great difference between the determinants of the etiology of individual cases, and the determinants of incidence rate in populations, in his words:

Within populations it has proved almost impossible to demonstrate any relation between an individual's diet and his serum cholesterol level: and the same applies to the relation of individual diet to blood pressure and to overweight. But at the level of populations it is a different story. ... The determinants of incidence are not necessarily the same as the causes of cases.

See comments on Rose's paper in Ebrahim and Lau (2001); McCormick (2001); Hunt and Emslie (2001).

2. Causality and faulty correlations: a follow-up on the fallacy. Nowadays, more and more articles are being published presenting dubious causal correlations. Both Peller (1967) and Mervyn Susser (1973) discussed the fundamentals of causal relationships in epidemiology. They remain valid and important sources for the understanding of the problems affecting the establishment of valid correlations (Kaufman and Poole, 2000; Susser, 2001).

3. Black box epidemiology: it certainly is justified when no or little biological data on a disease is available.

4. Normality: Canguilhem discussed its double meaning. Rose reinforced the notion that that "laboratory 'ranges of normal' are based on what is common within the local population. What is common is all right, we presume".

5. Race: Homo sapiens is a monotypic species. As Rose stressed, "there is a broad tendency for genetic factors to dominate individual susceptibility.... Thus migrants, whatever the color of their skin, tend to acquire the disease rates of their country of adoption". Genetic characteristics such as the blood factor Rh are a more efficient reproductive isolating mechanism than skin color, ethnicity, culture, religious precepts, or social mores.

6. The misuse of ecological theories, ideas and terms. Medical ecology is based upon solid ecological principles. Also the careless use of categories or aggregates in interviews and surveys (Avila-Pires, 2011).

7. Risk. There is much confusion in the conceptualization of hazards, danger, threats, and risk. A recent reappraisal of the epidemiology of risk, human behavior, and the concept of healthy living was published by Castiel, Guilam, 
and Ferreira. Other good sources amid a copious literature are the papers by Lauritzen and Sachs (2001) and Armstrong (1995).

Let us not forget that to be alive inevitably carries substantial risk to life.

\section{REFERENCES}

1. Armstrong D. The rise of surveillance medicine. Sociol Health Ill 3: 393-404, 1995.

2. Avila-Pires FD. The use and mis-use of some ecological terms and concepts in epidemiology. Mem Inst Oswaldo Cruz 90: 561-564, 1995.

3. Avila-Pires FD. Fundamentos históricos da Ecologia. Holos. Ribeirão Preto, 1999.

4. Avila-Pires FD. Princípios de ecologia médica. UFSC. Florianópolis, 2000.

5. Avila-Pires FD. On the concept of disease. Rev Hist Humanid Méd 4: 1-18, 2008.

6. Avila-Pires FD. Human ecology, statistical analysis, and the logic of valid correlations. Politica e Sociedade 10: 57-69, 2011.

7. Bergandi D. "Reductionist holism": an oxymoron or a philosophical chimera of EP Odum's systems ecology? Ludus Vitalis 3: 145-180, 1995.

8. Bernard C. Leçons sur les phénomènes de la vie comuns aux animaux et aux végétaux. 2 vols. JB. Baillière. Paris, 1878-1879.

9. Bertalanffy L. An Outline of General System Theory. Brit J Phil Sci 1: 134-165, 1950.

10. Bertalanffy L. An Outline of a General Systems Theory. G. Braziller. New York, 1968.

11. Bradby H. Race, ethnicity and health: the costs and benefits of conceptualising racism and ethnicity. Soc Sci Med 75: 955-958, 2012.

12. Canguilhem G. Essai sur quelques problèmes concernant le normal et le pathologique. PUF/ Quadrige. Paris, 1943. Reprinted (6 $6^{\text {th }}$ ed as Le Normal et le Pathologique, Nouvelles Réflexions concernant le normal et le pathologique. PUF/Quadrige. Paris, 1996.

13. Castiel LD, Guilam MCR, Ferreira MS. Correndo o risco: uma introdução aos riscos em saúde. Fiocruz. Rio de Janeiro, 2010.

14. Chia K. Editorial: Epidemiology in the post-genomic era. Ann Acad Med 29: 695-697, 2000.

15. Clements F, Shelford V. Bio-ecology. John Wiley. NewYork, 1939.

16. Comte A. Course de philosophie positive. Vol. IV. Bachelier, Paris, 1839.

17. Coura JR. Épidémiologie. In Lecourt, D. Dictionnaire de la pensée médicale. Presse Universitaire de France. Paris, 2004.

18. Darwin C. On the origin of species by means of natural selection, or the preservation of favoured races in the struggle for life. [quotation :69]. John Murray. London, 1859.

19. Diez-Roux A. Bringing context back into epidemiology: variables and fallacies in multilevel analysis. Amer J Publ Health 88: 216-222, 1998.

20. Durkheim E. Les règles de la méthode sociologique. Felix Alcan. Paris, 1894.

21. Ebrahim S, Lau E. Commentary: Sick populations and sick individuals. Int $J$ Epidemiol 30: 433-434, 2001.

22. Goldberg M. Cet obscur objet de l'épidémiologie. Sci Sociol Santé 1: 55-105, 1982.

23. Greenland S, Robins J. Identifiability, exchangeability, and epidemiological confounding. Int $J$ Epidemiol 15: 412-418, 1986.

24. Greenland S, Gago-Dominguez M, Castelão JE. The Value of risk-factor ("black-box") epidemiology. Epidemiology 15: 529-535, 2004.

25. Haeckel E. Generelle Morphologie der Organismen: Algmeine Grundzüge der organischen Formen-Wissenschaft, mecanisch begründet durch die von Charles Darwin reformiste DescendenzTheorie. 2 vols. Georg Reimer. Berlim, 1866.

26. Huff D. How to lie with statistics. Penguin. London. 1954.

27. Hunt K, Emslie C. Commentary: The prevention paradox in lay epidemiology - Rose revisited. Int J Epidemiol 30: 442-446, 2001. 
28. Kaufman JS, Poole C. Looking back on "Causal thinking in the health sciences". An Rev Pub Health 21: 101-119, 2000.

29. Koopman JS. Comment: Emerging objectives and methods in epidemiology. Amer J Pub Health 86: 630-632, 1996.

30. Krieger N. Epidemiology and the web of causation: has anyone seen the spider? Soc Sc Med 39: 887-903, 1994.

31. Lauritzen SO, Sachs L. Normality, risk, and the future: implicit communication of threat in health surveillance. Sociol Health Ill 23: 497-516, 2001.

32. Linnaeus C. L'Équilibre de la nature. J.Vrin. Paris, 1972.

33. Loomis D, Wing S. Is molecular epidemiology a germ theory for the end of the Twentieth Century? Int J Epidemiol 19: 1-3, 1990.

34. MacMahon B, Pugh TF, Ipsen J. Epidemiologic methods. Little Brown. Boston, 1960.

35. March D, Susser E. The eco - in eco-epidemiology. Int J Epidemiol 35: 1379-1383, 2006.

36. Marx K, Engels F. The Individual and Society: Progress Publishers. Moscow, 1984.

37. McCormick J. Commentary: Reflections on sick individuals and sick populations. Int J Epidemiol 30: 434-435, 2001.

38. Morabia A. Annotation: From disease surveillance to the surveillance of risk factors. Amer J Pub Health 86: 625-627, 1996.

39. Morgenstern H. Uses of ecologic analysis in epidemiological research. Amer J Pub Health 72: 1336-1344, 1982.

40. Morris JN. Uses of epidemiology. Livingstone. Edinburgh, 1957.

41. Morse S. Tuberculosis susceptibility: "race", "ethnicity", "nationality”. Owner-promed @usa. healthnet.org Acesso em 8 Dec, 1995.

42. Omran AR. The epidemiological transition: A theory of the epidemiology of population change. The Milbank Memorial Fund Quarterly 49: 509-538, 1971.

43. Pasteur L. Mémoire sur la fermentation appelée latique. Mém Soc Sci Agron Arts Lille 5: 13-26 1857 (1858).

44. Pearce N. Traditional epidemiology, modern epidemiology, and public health. Amer J Pub Health 86: 678-683, 1996.

45. Peller S. Quantitative research in human biology and medicine. John Wright. Bristol, 1967.

46. Pena SD. Humanidade sem raças?. Publifolha. São Paulo, 2008.

47. Peto R. The need for ignorance in cancer research. In Duncan R, Weston-Smith M. The Encyclopedia of Medical Ignorance. Oxford. Pergamon Press, 1984.

48. Pino C, Hernández G. En torno al significado original del vocablo griego epidemia y su identificación con el latino pestis. Dynamis 28: 199-215, 2008.

49. Poole C. Editorial: Ecological analysis as outlook and method. Amer J Pub Health 84: 715-716, 1994.

50. Portnov BA, Dubnov J, Barc M. Ecological fallacy, assessment errors stemming from misguided variable selection, and the effect of aggregation on the outcome of epidemiological study. $J$ Expos Sci Environ Epidemiol 17: 106-121, 2007.

51. Robinson W. Ecological correlations and the behavior of individuals. Amer Sociol Review 15: 351-357, 1950. Reprinted Int J Epidemiol 38: 337-341, 2009.

52. Root M. The use of race in medicine as a proxy for genetic differences. Phil Sci 70: 1173-1183, 2003.

53. Rose G. Sick individuals and sick populations. Int J Epidemiol 14: 32-38, 1985. Reprinted Int J Epidemiol 30: 427-432, 2001.

54. Rothman K. The rise and fall of epidemiology. Int J Epidemiol 36: 708-710, 2007.

55. Rumney J. Herbert Spencer's sociology. Williams and Norgate. London, 1934.

56. Schwartz S. The fallacy of the ecological fallacy: the potential misuse of a concept and the consequences. Amer J Pub Health 84: 819-824, 1994.

57. Schwartz S, Diez-Roux A. Commentary: causes of incidence and causes of cases - a Durkheimian perspective on Rose. Int J Epidemiol 30: 435-439, 2001.

58. Schwartz S, Susser E, Susser M. A future for epidemiology? An Rev Pub Health 20: 15-33, 1999. 
59. Selvin HC. Durkheim's suicide and problems of empirical research. Am J Soc 63: 607-619, 1958.

60. Serfling RE. Historical review of epidemic theory. Hum Biol 24: 115-166, 1952.

61. Shelford VE. Animal communities in temperate America. Bull Geogr.Assoc Chicago 5: 1-368, 1913. Reprinted, University Chicago Press. Chicago, 1937.

62. Smaje C. The ethnic patterning of health: new directions for theory and research. Soc Health Ill 18: 139-171, 1996.

63. Stallones R. To advance epidemiology. An Rev Pub Health 1: 69-82, 1980.

64. Susser E. [zra] Eco-epidemiology: thinking outside the black-box. Epidemiology 15: 519-520, 2004.

65. Susser M. Causal thinking in the the health sciences. Concepts and strategies in epidemiology. Oxford University Press. New York, 1973.

66. Susser M. Epidemiology today: 'a thought-tormented world'. Int J Epidemiol 18: 481-488, 1989.

67. Susser M. Does risk factor epidemiology put epidemiology at risk? Peering into the future. $J$ Epidemiol Community Health 52: 608-611, 1998.

68. Susser M. Glossary: causality in public health science J Epidemiol Community Health 55: 376-378, 2001.

69. Susser M. Eco-Epidemiology: thinking outside the black box. Epidemiology 15: 519-520, 2004.

70. Susser M, Susser E. Choosing a future for epidemiology: I Eras and paradigms. Amer J Pub Health 86: 668-673, 1996a.

71. Susser M, Susser E. Choosing a future for epidemiology: II. From black box to Chinese boxes and eco-epidemiology. Amer J Pub Health 86: 674-677, $1996 \mathrm{~b}$.

72. Susser M, Stein Z. Eras in Epidemiology: The Evolution of Ideas. Oxford University Press. Oxford, 2009.

73. Tansley AG. The use and abuse of vegetational concepts and terms. Ecology 16: 284-307, 1935.

74. Templeton AR. Human races: a genetic and evolutionary perspective. Amer Anthropol 100: 632-650, 1999.

75. The New England Journal of Medicine. The great debate continues. The New Engl J Med 265: 294, 1961.

76. Tyndall J. Essays on the Floating-matter of the Air in relation to Putrefaction and Infection. Longamns, Green. London, 1881.

77. Weber M. Essays in sociology. Routledge. Oxon, 1991.

78. Weed DL. Beyond black box epidemiology. Amer J Pub Health 88: 12-14, 1998. 